\title{
Effect of the number of boluses and time of administration on ruminants' fecal excretion pattern of chromium oxide'
}

\author{
Américo Casas, ${ }^{2}$ Danilo Cianzio ${ }^{3}$ and José A. Arroyo-Aguilú
}

J. Agric. Univ. P.R. 83(3-4):123-134 (1999)

\begin{abstract}
A study was conducted to compare the effectiveness of administering one bolus of $15 \mathrm{~g}$ of chromium oxide $\left(\mathrm{Cr}_{2} \mathrm{O}_{3}\right)$ at 8 am or $4 \mathrm{pm}$ versus two boluses of $7.5 \mathrm{~g}$ each at 8 am and $4 \mathrm{pm}$. The daily excretion pattern of $\mathrm{Cr}_{2} \mathrm{O}_{3}$ was determined to estimate the best time of day to take rectal fecal samples from each animal. Twelve Holstein and Brown Swiss heifers of $282.5 \mathrm{~kg}$ mean live weight were used in a complete randomized design. The animals grazed a mixture of improved tropical grass pastures during the entire trial. There were no significant differences among treatments. Neither the number of boluses (one vs. two) nor the time of administration ( $8 \mathrm{am}$ and/or $4 \mathrm{pm}$ ) had a significant effect upon the total mean concentration of $\mathrm{Cr}_{2} \mathrm{O}_{3}$ in dry feces $(\mathrm{mg} / \mathrm{g})$, collected twice per day $(8 \mathrm{am}$ and $4 \mathrm{pm})$ for seven days. Higher simple correlation coefficients $(P<0.01)$ were obtained between the total fecal $\mathrm{Cr}_{2} \mathrm{O}_{3}$ average concentration on the 4 th day and the mean concentration from two fecal samples collected at different hour-combinations. The more reliable morning and afternoon hour combinations for sampling feces were 8 am and $6 \mathrm{pm}(r=0.94)$ and 10 am and $6 \mathrm{pm}(r=0.92)$. Three days was found to be the minimum time required for the stabilization of the $\mathrm{Cr}_{2} \mathrm{O}_{3}$ concentration in dry feces.
\end{abstract}

Key words: chromium oxide, feces output, grazing animals, pasture intake, external indicator

\section{RESUMEN}

Efecto del número de bolos y hora en que se suministran sobre el patrón de excreción de oxido crómico en rumiantes

Se realizó un estudio en la Subestación de Lajas para comparar la efectividad del suministro diario, a las 8 am o $4 \mathrm{pm}$, de un bolo de $15 \mathrm{~g}$ de óxido crómico $\left(\mathrm{Cr}_{2} \mathrm{O}_{3}\right)$ versus dos bolos de $7.5 \mathrm{~g}$ cada uno, a las $8 \mathrm{am}$ y $4 \mathrm{pm}$, en la estimación de la producción total de materias fecales. Se utilizaron un total de 12 novillas Holstein y Pardo Suizo, de $282.5 \mathrm{~kg}$ de peso vivo promedio, en un diseño completamente al azar. Las novillas pastaron una asociación de gramineas tropicales por la duración del estudio. No se encontraron dife-

'Submitted to Editorial Board 20 March 1996.

"Assistant Animal Nutritionist, Department of Animal Industry. Agricultural Experiment Station, P. O. Box 21360, San Juan, P.R. 00928.

"Professor, Department of Animal Industry. Univ. P.R., Mayagüez Campus, Mayagüez, P.R.

'Consultant, Agricultural Experiment Station. San Juan, P.R. 
rencias signíficativas entre tratamientos. El número de bolos de $\mathrm{Cr}_{2} \mathrm{O}_{3}$ por día (uno vs. dos), asi como la hora del dia en que se administraron ( 8 am y/o $4 \mathrm{pm})$, no tuvieron efectos significativos sobre el promedio total de la concentración del indicador en las heces secas $(\mathrm{mg} / \mathrm{g})$. Las muestras de heces se tomaron directamente del recto del animal a las 8 am y $4 \mathrm{pm}$, durante siete dias. El promedio de concentración de $\mathrm{Cr}_{2} \mathrm{O}_{3}$ de dos muestras diarias de materias fecales resultó ser más confiable que la información obtenida con una sola muestra de heces. Los coeficientes de correlación simple entre la concentración de $\mathrm{Cr}_{2} \mathrm{O}_{3}$ en las muestras y el promedio general para el total diario de heces recogidas fue significativamente más alto $(P<0.01)$ para la combinación de muestras tomadas a las 8 am y $6 \mathrm{pm}(r=0.94)$ y 10 am y $6 \mathrm{pm}(r=0.92)$. También se determinó que tres días es el mínimo requerido para estabilizar la concentración del $\mathrm{Cr}_{2} \mathrm{O}_{3}$ en las heces durante el período de preparación.

\section{INTRODUCTION}

The nutritive value of forages depends upon their chemical composition and digestibility. Feed intake and feces output during a given period of time are used to measure digestibility (Ramírez-Reyes, 1971). The direct and classical method of measuring digestibility utilizes individual feeding of animals in confinement (Nelson et al., 1954). Results thus obtained may not necessarily represent the real situation in pasture since grazing behavior of cattle is characterized by animal selection of the plant structures (Schneider and Flatt, 1975).

Pasture digestibility may be measured with grazing animals. Two types of problems that arise in this procedure are collection of representative samples of the forage being consumed, and estimation of the daily feces output (McDonald et al., 1975). To overcome these problems, indirect methods using chemical compounds as indicators have been developed. These chemicals are of two types: those normally found in plant material as lignin, silica, and chromogens (internal indicators), and those administered to the animals in fixed doses (external indicators). Of the latter the most commonly used is chromium oxide, $\mathrm{Cr}_{2} \mathrm{O}_{3}$ (Yiakoulaki et al., 1997). The external indicators are used to estimate fecal production, whereas internal indicators allow the determination of forage digestibility (Olubajo and Oyenuga, 1970; Pond et al., 1987).

The reliability of the data obtained through indirect methods may be affected by several factors. Among the most important are the time of the day as well as the dosage and frequency of administration of the external indicator (Hattan and Owen, 1970; Streeter, 1969), the indigestibility and fecal excretion rate of the indicators (Arroyo-Aguilú and Evans, 1970; Elam et al., 1962), and the homogeneity of the pasture sample collected (Cook, 1964).

The determination of pasture intake and digestibility by grazing animals is an important requirement in grass evaluation programs. In Puerto Rico, livestock production depends to a considerable degree 
upon grassland utilization, however there is no published information on the adjustment of the indirect methodology for estimating pasture intake and digestibility to the physiographic conditions of cattle production. The objective of this study, conducted at the Lajas Substation, was to compare the effectiveness of one versus two daily boluses of $\mathrm{Cr}_{2} \mathrm{O}_{3}$ in fecal output determinations, to establish the daily indicator excretion pattern for the determination of the most appropriate time of the day to sample feces from the rectum, and to estimate the number of days required for $\mathrm{Cr}_{2} \mathrm{O}_{3}$ to reach the overall mean concentration in dry feces.

\section{MATERIALS AND METHODS}

A total of 12 Holstein and Brown Swiss heifers of similar age and $282.5 \mathrm{~kg}$ average live weight were used in the study. They were either nonpregnant or in the initial stages of gestation. Four heifers were randomly assigned to each of the following treatment groups: $\mathrm{T} 1$, one bolus of $15 \mathrm{~g}$ of $\mathrm{Cr}_{2} \mathrm{O}_{3}$ at 8 am daily; $\mathrm{T} 2$, one bolus of $15 \mathrm{~g}$ of $\mathrm{Cr}_{2} \mathrm{O}_{3}$ at $4 \mathrm{pm}$ daily; and T3, one bolus of $7.5 \mathrm{~g}$ of $\mathrm{Cr}_{2} \mathrm{O}_{3}$ at 8 am and 4 pm daily. Boluses were molded with paraffin paper and administered orally to the heifers during two periods of seven days each (preparation and sampling week), according to the treatments. Previous to these periods, the heifers were allowed to graze the pasture for seven days (adaptation week).

The grazing area of 3.9 ha was divided into 10 paddocks of 0.39 ha each. The pasture was a mixture of Railroad track grass (Dichanthrium annulatum Forsk. Stapf), Stargrass (Cynodon nlemfuensis Vanderyst var, nlemfuensis), Caribgrass (Eriochloa polystachya H.B.K.), Pará grass (Brachiaria purpurascens Raddi. Henr.) and Guinea grass (Panicum maximum Jacq.). Three months before initiating the grazing phase the paddocks were mowed and fertilized with $445 \mathrm{~kg} / \mathrm{ha}$ of a 15 5-10 formula. Natural rainfall was sufficient to maintain abundant forage throughout the study.

\section{Collection of fecal material}

Approximately $250 \mathrm{~g}$ of feces was removed daily from the rectum of each heifer at 8 am and $4 \mathrm{pm}$. Collection was initiated the second day after the administration of $\mathrm{Cr}_{2} \mathrm{O}_{3}$ began (preparation period), and continued until the end of the trial. Each sample was deposited in a polyethylene bag and kept frozen at $-23^{\circ} \mathrm{C}$ prior to chemical analysis of chromium (Cr). During day four of the sampling period, each rectum was emptied of feces every two hours. The total weight of feces collected in this manner was used to estimate the total fecal production per animal. 
Fecal dry matter (FDM) determination

The frozen fecal samples were thawed at room temperature for $24 \mathrm{~h}$, weighed and dried in a convection oven at $60^{\circ} \mathrm{C}$ for $24 \mathrm{~h}$ and then at $90^{\circ} \mathrm{C}$ for another $24 \mathrm{~h}$. The dried samples were weighed and ground in a small laboratory hammer-mill. Each sample was identified and analyzed separately.

\section{Chromium analysis}

The technique described by Kimura and Miller (1957) was followed for the analysis of chromium oxide $\left(\mathrm{Cr}_{2} \mathrm{O}_{3}\right)$. The concentration of chromium $(\mathrm{Cr}$ ) in each fecal sample expressed as $\mathrm{mg}$ of $\mathrm{Cr} / \mathrm{g}$ FDM was converted to mg of $\mathrm{Cr}_{2} \mathrm{O}_{3}$, using the following formula:

$$
\mathrm{Cr}_{2} \mathrm{O}_{3}(\mathrm{mg} / \mathrm{g} \mathrm{FDM})=\frac{1 \text { Molecular weight } \mathrm{Cr}_{2} \mathrm{O}_{3}}{2 \text { Atomic weight } \mathrm{Cr}} \times \mathrm{Cr}(\mathrm{mg} / \mathrm{g} \text { FDM })
$$

Determination of the daily recovery of $\mathrm{Cr}_{2} \mathrm{O}_{3}$

The mean fecal recovery of $\mathrm{Cr}_{2} \mathrm{O}_{3}$ expressed as a percentage of the amount of $\mathrm{Cr}_{2} \mathrm{O}_{3}$ administered daily was obtained for each heifer by the following formula:

$$
\begin{aligned}
& \text { Recovery of fecal } \mathrm{Cr}_{2} \mathrm{O}_{3} \text { per day }(\%)= \\
& \frac{\text { Fecal } \mathrm{Cr}_{2} \mathrm{O}_{3}(\mathrm{~g} / \mathrm{g} \text { FDM }) \times \text { FDM collected (g/day) }}{\mathrm{Cr}_{2} \mathrm{O}_{3} \text { administered }(\mathrm{g} / \text { day })} \times 100
\end{aligned}
$$

where the daily output of FDM was obtained indirectly, during day four of the sampling period, by emptying each rectum of feces every two hours.

\section{Statistical analysis}

Treatment means were compared by analysis of variance and orthogonal comparisons in a completely randomized design. Treatments were considered fixed effects, and days and animals as random effects (Snedecor and Cochran, 1967). The dependent variables analyzed were the daily mean concentration of $\mathrm{Cr}_{2} \mathrm{O}_{3}$ (mg/g FDM) and the fecal concentration of $\mathrm{Cr}_{2} \mathrm{O}_{3}(\mathrm{mg} / \mathrm{g} \mathrm{FDM})$ in each sample collected at different hours during the fourth day of the sampling period. Concentration of $\mathrm{Cr}_{2} \mathrm{O}_{3}$ in dry feces $(\mathrm{mg} / \mathrm{g}$ ) was chosen, instead of its recovery percentage, as the dependent variable for comparing treatments because the technique of emptying the rectum every two hours was not successful. Daily 
fecal output was underestimated because of the incompleteness of fecal collection. Therefore, the mean $\mathrm{Cr}_{2} \mathrm{O}_{3}$ recovery in feces was much less than the expected $100 \%$. The mean value obtained for the 12 heifers during the fourth day of the sampling week was only $31.9 \pm 14.2 \%$. To estimate the most suitable hour of the day to sample feces from the rectum, a simple correlation coefficient was calculated for each animal between the daily mean fecal $\mathrm{Cr}_{2} \mathrm{O}_{3}$ concentration and the mean concentration of the indicator in fecal samples obtained every two hours during the fourth day of sampling.

\section{RESULTS}

$\mathrm{Cr}_{2} \mathrm{O}_{3}$ concentration (mg/g FDM) in fecal samples reached the overall mean value three days after initiating its administration (Table 1 ). The mean $\mathrm{Cr}_{2} \mathrm{O}_{3}$ content for all fecal samples collected during the preparation week was $4.14 \mathrm{mg} / \mathrm{g} F D M$, whereas the treatment means for the third day of that week were $\mathrm{T} 1,4.23 ; \mathrm{T} 2,4.59$; and $\mathrm{T} 3,3.87 \mathrm{mg} / \mathrm{g}$ FDM.

There were no significant effects for the number of boluses administered daily (one vs. two) nor for the hour of their administration ( 8 am and/or $4 \mathrm{pm}$ ) upon the mean $\mathrm{Cr}_{2} \mathrm{O}_{3}$ concentration in dry feces collected during the sampling week (Table 2). Consequently, the daily fecal out-

TABLE 1.-Mean concentrations and standard deviations (SD) of chromium oxide in dry feces per day and treatment, during the preliminary period'

\begin{tabular}{lccc}
\hline & \multicolumn{3}{c}{ Treatment $^{2}$} \\
\cline { 2 - 4 } Day & $\mathrm{T}_{1}$ & $\mathrm{~T}_{2}$ & $\mathrm{~T}_{3}$ \\
\hline & & $\mathrm{mg} / \mathrm{g}$ FDM \\
Tuesday & $3.18 \pm 0.59$ & $3.40 \pm 1.16$ & $3.11 \pm 0.53$ \\
Wednesday & $4.23 \pm 0.61$ & $4.59 \pm 0.27$ & $3.87 \pm 0.61$ \\
Thursday & $4.17 \pm 1.01$ & $3.99 \pm 0.37$ & $5.66 \pm 0.50$ \\
Friday & $3.36 \pm 1.06$ & $4.32 \pm 1.09$ & $4.50 \pm 1.08$ \\
Saturday & $3.78 \pm 0.58$ & $4.45 \pm 0.41$ & $4.95 \pm 0.47$ \\
Sunday & $4.03 \pm 0.15$ & $4.01 \pm 0.69$ & $4.84 \pm 0.09$ \\
Treatment mean $\pm \mathrm{SD}$ & $3.79 \pm 0.43$ & $4.12 \pm 0.42$ & $4.49 \pm 0.89$ \\
Overall mean $\pm \mathrm{SD}$ & & $4.14 \pm 0.66$ & \\
\hline
\end{tabular}

'Means of four heifers $x$ two daily samples of feces ( 8 am and $4 \mathrm{pm}$ ). Administration of chromium oxide started Monday of preliminary period.

${ }^{2} \mathrm{~T}_{1}: 1$ bolus $\left(15 \mathrm{~g} \mathrm{Cr}_{2} \mathrm{O}_{3}\right.$ ) at $8 \mathrm{am} ; \mathrm{T}_{2}: 1$ bolus at $4 \mathrm{pm} ; \mathrm{T}_{3}: 1$ bolus $(7.5 \mathrm{~g})$ at 8 am and 4. pm, respectively. 
TABLE 2.-Analysis of variance for the mean $\mathrm{Cr}_{2} \mathrm{O}_{3}$ concentration ( $\mathrm{mg} / \mathrm{g} \mathrm{FDM}$ ) and orthogonal contrasts among trealments.

\begin{tabular}{lcc}
\hline Source of variation & Degree of freedom & Mean square \\
\hline Treatment $(T)^{\prime}$ & 2 & 0.524 \\
I vs. 2 & 1 & 0.241 \\
1,2 vs, 3 & 1 & 0.807 \\
Day (D) & 6 & 2.570 \\
D $\times$ T & 12 & 1.123 \\
Animals/T, D & 49 & 0.969
\end{tabular}

'T1: 1 bolus ( $15 \mathrm{~g} \mathrm{Cr}_{2} \mathrm{O}_{3}$ ) at $8 \mathrm{am} ; \mathrm{T2}: 1$ bolus at $4 \mathrm{pm}$; T3: 1 bolus ( $7.5 \mathrm{~g}$ ) at 8 am and $4 \mathrm{pm}$, respectively.

Significant $(\mathrm{P}<0.05)$.

put may be estimated by the administration of one bolus of $15 \mathrm{~g}$ of $\mathrm{Cr}_{2} \mathrm{O}_{3}$ at either 8 am and $4 \mathrm{pm}$, or by supplying two $7.5 \mathrm{~g}$ boluses daily one at 8 am and again at $4 \mathrm{pm}$ (Table 3 ).

Variation among and within days in fecal $\mathrm{Cr}_{2} \mathrm{O}_{3}$ concentration during the sampling week

Among days: The analysis of variance showed a significant effect $(\mathrm{P}<0.05)$ of days upon fecal $\mathrm{Cr}_{2} \mathrm{O}_{3}$ concentration (Table 2), but the interaction of days by treatments was nonsignificant. Figure 1 illustrates the daily variation of the treatment means $(\mathrm{n}=4)$ of $\mathrm{Cr}_{2} \mathrm{O}_{3}$ concentration (two fecal samples per animal) around the overall mean for the sampling week. Ranges and means per treatment were $\mathrm{T} 1=5.40,3.25$, and $4.05 ; \mathrm{T} 2=4.96,2.91$, and $4.10 ; \mathrm{T} 3=4.86,3.38$, and $4.02 \mathrm{mg} / \mathrm{g} \mathrm{FDM}$ (Table 3). T3 (two boluses of $7.5 \mathrm{~g}$ each daily) showed the least variation in fecal $\mathrm{Cr}_{2} \mathrm{O}_{3}$ concentration ( $\mathrm{SD}=0.55 \mathrm{mg} / \mathrm{g} \mathrm{FDM}$ ) during that week.

Within days: Figure 2 shows the $\mathrm{Cr}_{2} \mathrm{O}_{3}$ concentration in feces by treatment collected from the rectum every two hours during the fourth day of the sampling week. Fecal excretion pattern of $\mathrm{Cr}_{2} \mathrm{O}_{3}$ showed the greatest variation $(\mathrm{CV}=18.04 \%)$ in $\mathrm{T} 1$, whereas $\mathrm{T} 3$, where two boluses were administered, exhibited the smallest coefficient of variation $(\mathrm{CV}$ $=12.32 \%$ ). Also, increased $\mathrm{Cr}_{2} \mathrm{O}_{3}$ concentration in dry feces was observed during morning hours ( 6 am to $12 \mathrm{n}$ ) for T1 and T2, with one bolus administered daily (5.22 and $4.50 \mathrm{mg} / \mathrm{g}$ FDM, respectively); and during dawn hours ( 1 am to $5 \mathrm{am}$ ) for T3 ( $4.35 \mathrm{mg} / \mathrm{g}$ FDM).

\section{DISCUSSION}

A relatively stable indicator level in feces is of paramount importance for the reliability of fecal output estimations. Several researchers 
TABLE 3.-Mean concentrations and standard deviations (SD) of chromium oxide in dry feces per day during the sampling period. ${ }^{x}$

\begin{tabular}{lccc}
\hline & \multicolumn{3}{c}{ Treatment $^{2}$} \\
\cline { 2 - 4 } Day & $\mathrm{T}_{1}$ & $\mathrm{~T}_{2}$ & $\mathrm{~T}_{3}$ \\
\hline & \multicolumn{3}{c}{ mg/g FDM } \\
\cline { 2 - 4 } Monday & $3.63 \pm 0.29$ & $4.76 \pm 0.19$ & $3.60 \pm 0.35$ \\
Tuesday & $4.23 \pm 1.56$ & $4.75 \pm 0.26$ & $4.86 \pm 0.16$ \\
Wednesday & $3.25 \pm 0.71$ & $3.99 \pm 1.75$ & $4.27 \pm 0.81$ \\
Thursday & $4.48 \pm 0.78$ & $3.72 \pm 0.27$ & $3.60 \pm 0.39$ \\
Friday & $3.29 \pm 1.26$ & $2.91 \pm 0.73$ & $3.90 \pm 0.77$ \\
Saturday & $5.40 \pm 1.48$ & $4.96 \pm 1.32$ & $4.59 \pm 0.63$ \\
Sunday & $4.13 \pm 0.45$ & $3.63 \pm 0.63$ & $3.38 \pm 0.30$ \\
Total mean $\pm \mathrm{SD}$ & $4.05 \pm 0.75$ & $4.10 \pm 0.75$ & $4.02 \pm 0.55$ \\
\hline
\end{tabular}

'Means of four heifers $\times$ two daily samples of feces ( 8 am and $4 \mathrm{pm}$ ). Administration of chromium oxide started Monday of preliminary period.

${ }^{2} \mathrm{~T}_{1}: 1$ bolus $\left(15 \mathrm{~g} \mathrm{Cr}_{2} \mathrm{O}_{3}\right.$ ) at $8 \mathrm{am} ; \mathrm{T}_{2}: 1$ bolus at $4 \mathrm{pm} ; \mathrm{T}_{3}: 1$ bolus $(7.5 \mathrm{~g})$ at 8 am and $4 \mathrm{pm}$, respectively.

have recommended that the administration of $\mathrm{Cr}_{2} \mathrm{O}_{3}$ be a few days before initiation of the study. Kane et al. (1950) suggested 10 days, whereas other authors (Hardison et al., 1956) indicated that seven days was a sufficient preparation period. The present study indicated that after three days, fecal $\mathrm{Cr}_{2} \mathrm{O}_{3}$ concentration (mg/g FDM) was similar to that of the overall mean in the preparation week. Therefore, three days appears to be the minimum required for the level of $\mathrm{Cr}_{2} \mathrm{O}_{3}$ to stabilize in the feces. In agreement with these results Hardison et al. (1959) also found three days to be the minimum duration of a preparation period.

Although a uniform rate of indicator excretion is desired, the $\mathrm{Cr}_{2} \mathrm{O}_{3}$ concentration in feces varies between and within days (Hattan and Owen, 1970; Steeter, 1969). In this study, the mean fecal $\mathrm{Cr}_{2} \mathrm{O}_{3}$ concentration changed significantly $(\mathrm{P}<0.05)$ between days. The form of supplying the indicator (one vs. two boluses) did not have a significant effect (Table 2), yet two boluses daily ( $7.5 \mathrm{~g}$ each) showed a slightly lower variation as compared to only one bolus of $15 \mathrm{~g} /$ day. Hardison and Reid (1953) pointed out that fecal samples should be collected for several days because of day-to-day variation in the excretion rate of the indicator. Our results suggest that four days of sampling feces is sufficient to obtain a reliable estimate of the mean $\mathrm{Cr}_{2} \mathrm{O}_{3}$ concentration $(\mathrm{mg} / \mathrm{g}$ FDM). Increasing sampling from four to five days improved the precision of that estimation by only $0.0033 \mathrm{mg} / \mathrm{g}$ FDM (Table 4). 


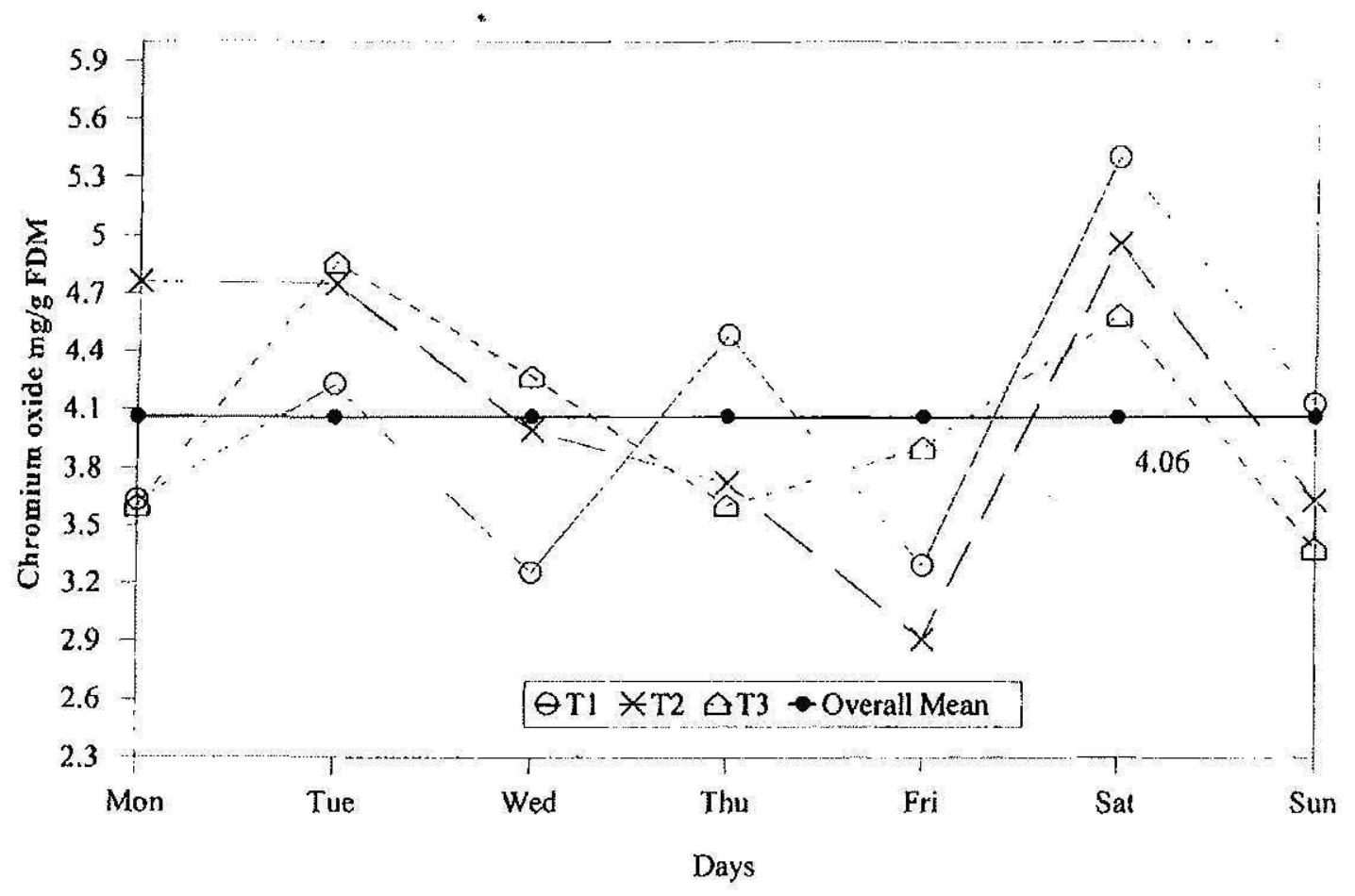
period.

FIGURE 1. Mean daily chromium oxide concentration in feces during the sampling

In agreement with other reports (Davis et al., 1958; Galyean et al., 1986 ), the within day variation in the fecal $\mathrm{Cr}_{2} \mathrm{O}_{3}$ concentration was reduced slightly when two boluses were administered daily to the heifers. Several factors could be responsible for that variation. The amount of forage eaten by the animal changes throughout the day; sunrise and sunset are the predominant grazing periods (Balch et al., 1957). Therefore, variation of indicator concentration in fecal samples may be expected according to the pattern of forage intake during the day (Hardison and Reid, 1953). This is due to the movement and mixing of the indicator with the ingesta in the reticulo-rumen (Johnson et al., 1964) as well as the relatively high specific gravity of the $\mathrm{Cr}_{2} \mathrm{O}_{3}$ (King and Moore, 1957). The literature suggests that the $\mathrm{Cr}_{2} \mathrm{O}_{3}$ does not mix well with the solid or soluble components of the ingesta (Udén et al., 1980). This finding accounts for the recommendation of indicator administration before the peak hours of grazing to assure a more uniform passage of the indicator throughout the reticulo-omasum orifice (Balch et al., 1957). This is coincidental with greater movements of the ingesta out of the rumen, and in turn would reduce the variation of $\mathrm{Cr}_{2} \mathrm{O}_{3}$ concentration in the feces. In the present study, the coincidence of dosage with grazing behavior may partially explain the smaller variation in fecal $\mathrm{Cr}_{2} \mathrm{O}_{3}$ concentration found in $\mathrm{T} 3$, where two boluses were administered per day ( 8 am and $4 \mathrm{pm}$ ). 


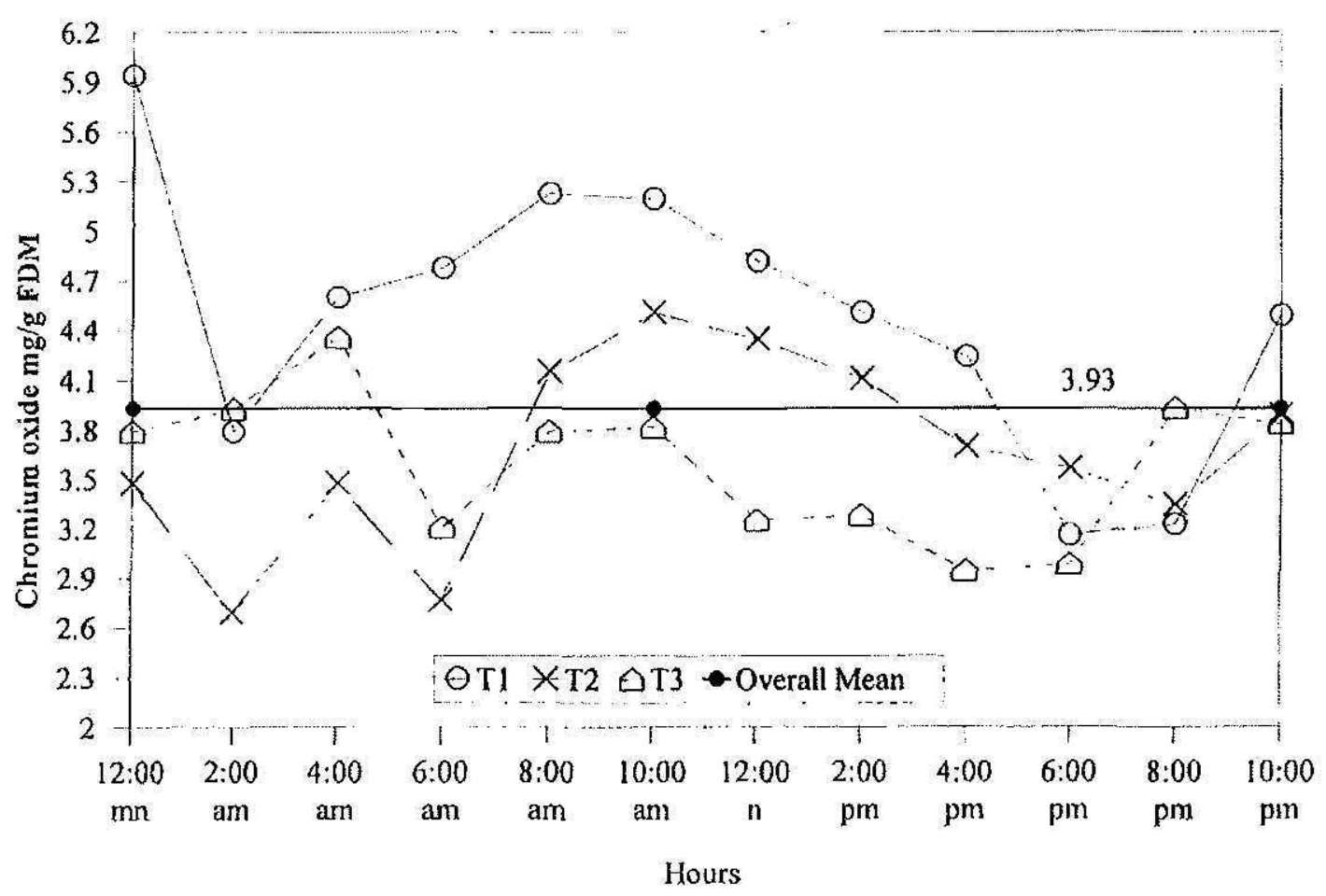

Figure 2. Mean chromium oxide concentration in feces during the fourth day of the sampling period.

A different approach to the same problem was discussed by Prigge et al. (1981), who pointed out that a suitable fecal sampling scheme might be more effective than the number of boluses to reduce the daily variation in fecal $\mathrm{Cr}_{2} \mathrm{O}_{3}$ excretion. The best sampling hours are selected on the basis of the association between $\mathrm{Cr}_{2} \mathrm{O}_{3}$ concentration in grab samples removed at different times and its total fecal mean for the day. Therefore, a simple correlation analysis was performed by pooling all the data from individual heifers during the fourth day of the sampling week, since the concentration of fecal $\mathrm{Cr}_{2} \mathrm{O}_{3}$ was not significantly differ-

TABLE 4.-Effect of increasing the number of sampling days upon the variation of the total mean concentration of fecal chromium oxide ( $\mathrm{mg} / \mathrm{g}$ FDM).

\begin{tabular}{lcc}
\hline Day & Standard error due to days & $\begin{array}{c}\text { Precision increment in } \\
\text { estimating the total mean }\end{array}$ \\
\hline 1 & 0.2435 & 0.0714 \\
2 & 0.1721 & 0.0316 \\
3 & 0.1405 & 0.0188 \\
4 & 0.1217 & 0.0128 \\
5 & 0.1089 & 0.0095 \\
6 & 0.0994 & 0.0095 \\
\hline
\end{tabular}


TABLE 5 . Simple correlation coefficients between the mean $\mathrm{Cr}_{2} \mathrm{O}_{3}$ concentration from two fecal samples at different hour-combinations and the total mean fecal concentration on the $4^{\text {th }}$ day of the sampling period.

\begin{tabular}{|c|c|c|}
\hline Hour-combination of sampling feces & Correlation coefficient & Degrees of freedom \\
\hline $6 \mathrm{am}-2 \mathrm{pm}$ & $0.88^{*}:$ & 9 \\
\hline 6 am-4 pm & $0.78^{: * *}$ & 9 \\
\hline $6 \mathrm{am}-6 \mathrm{pm}$ & 0.49 & 7 \\
\hline 8 am-2 pm & 0.87 & 9 \\
\hline $8 \mathrm{am}-4 \mathrm{pm}$ & $0.83^{* ;:}$ & 10 \\
\hline $8 \mathrm{am}-6 \mathrm{pm}$ & 0.94 & 7 \\
\hline $10 \mathrm{am}-2 \mathrm{pm}$ & $0.75^{*}$ & 8 \\
\hline $10 \mathrm{am}-4 \mathrm{pm}$ & 0.60 & 8 \\
\hline $10 \mathrm{am}-6 \mathrm{pm}$ & 0.92 & 7 \\
\hline $12 m-2 p m$ & $0.76^{* \cdots: k}$ & 9 \\
\hline $12 \mathrm{~m}-2 \mathrm{pm}$ & 0.64 & 10 \\
\hline
\end{tabular}

"Significant at the $5 \%$ level.

*:Significant at the $1 \%$ level.

ent among treatments (Table 2). The fecal sample removed at 6 am was found to be the single most reliable predictor of the total mean concentration of the indicator in the feces $(r=0.78 ; \mathrm{P}<0.01)$. Several other studies have suggested the convenience of taking two samples of feces during the day to improve the precision of that estimation (Davis et al., 1958; Galyean et al., 1986). Table 5 shows the correlation coefficients found in this study for the mean $\mathrm{Cr}_{2} \mathrm{O}_{3}$ concentration in two fecal samples taken at different hour-combinations. The best combination was 8 am and $6 \mathrm{pm}(\mathrm{r}=0.94 ; \mathrm{P}<0.01)$. Although taking a single fecal sample is less costly and time consuming, simple correlation coefficients were higher for the mean of two daily samples. This finding is in agreement with previously published results (Galyean et al., 1986; Lusk et al., 1961). Hence, election of the most suitable hour-combination to collect fecal samples will depend on the objectives and resources of each study in particular.

The main conclusions derived from this study are that the $\mathrm{Cr}_{2} \mathrm{O}_{3}$ concentration in feces ( $\mathrm{mg} / \mathrm{g}$ FDM) reached a stable level the third day after administration started, thus suggesting that three days is the minimum time required for the preparation period. One bolus or two boluses were equally effective for supplying the daily amount of $\mathrm{Cr}_{2} \mathrm{O}_{3}(15 \mathrm{~g})$ to estimate the mean fecal indicator concentration. The excretion pattern of $\mathrm{Cr}_{2} \mathrm{O}_{3}$ in the feces suggested that daily collection of two fecal samples directly from the rectum is recommended. The best hour-combinations for sample collection are those between 6 to 8 am and 2 to $4 \mathrm{pm}$. 


\section{LITERATURE CITED}

Arroyo-Aguilú, J. A. and J. L. Evans, 1970. The use of chromium and acid detergent lignin in complete rations as indicators of the fecal excretion rate in the ruminant animal. J.Agric. Univ. P.R. 54(4):660-675.

Balch, C. C., J. T. Reid and J. W. Stroud, 1957. Factors influencing the rate of excretion of administered chromium sesquioxide by steers. Brit. J. Nutr. 11:184-197.

Cook, C. W., 1964. Symposium on nutrition of forages and pastures: Collecting forage samples representative of ingested material of grazing animals for nutritional studies. J. Anim. Sci. 23:265-270.

Davis, C. L., J. H. Bayers and L. E. Luber, 1958. An evaluation of the chromic oxide method for determining digestibility. J. Dairy Sci. 41:152-159.

Elam, C. J., P. J. Reynolds, R. E. Davis and D. O. Everson, 1962. Digestibility studies by means of chromic oxide, lignin, and total collection techniques with sheep. J. Anim. Sci. 21:189-192.

Galyean, M. L., L. J. Krysl and R. E. Estell, 1986. Marker-based approaches for estimation of fecal output and digestibility in ruminants. In F. N. Owens (ed.) Feed Intake by Beef Cattle: Symposium pp. 96-113. Oklahoma Agric. Exp. Sta. MP-121.

Hardison, W. A., R. W. Engel, W. N. Linkous, H. C. Sweeney and G. C. Graf, 1956. Fecal chromic oxide concentration in 12 dairy cows as related to time and frequency of administration and to feeding schedule, J. Nutr. 58:11-17.

Hardison, W. A., W. N. Linkous, R. W. Engel and G. C. Graf, 1959. Observations on the use of chromic oxide for estimating the fecal output of dairy animals. J. Dairy Sci. 42:346-352.

Hardison, W. A. and J. T. Reid, 1953. Use of indicators in the measurement of the dry matter intake of grazing animals. J. Nutr. 51:35-52.

Hattan, G. L. and F. G. Owen, 1970. Efficiency of total collection and chromic oxide technique in short-term digestion trials. J. Dairy Sci. 53:325-329.

Johnson, D. E., W. E. Dinusson and D. W. Bolin, 1964. Rate of passage of chromic oxide and composition of digesta along the alimentary tract of wethers. J. Anim. Sci. 23:499-505.

Kane, E. A, W. C. Jacobson and L. A. Moore, 1950. A study of the use chromium oxide and lignin as indicators of digestibility. J. Dairy Sci. 33:385 (Abs.).

Kimura, F. T. and V. L. Miller, 1957. Improved determination of chromic oxide in cow feed and faeces. J. Agr: Food Chem. 5:216.

King, K. W. and W. E. C. Moore, 1957. Density and size as factors affecting passage rate of ingesta in the bovine and human digestive tracts. J. Dairy Sci. 40:528-536.

Lusk, W. C., M. B. Jones, D. T. Torell and C. M. McKell, 1961. Medusa-head palatability. J. Range Mgt. 14:248-251.

McDonald, P., R. A. Edwards and J. F. D. Greenhalgh, 1975. Nutrición Animal, 2da ed, Editorial Acribia, España.

Nelson, A. B., A. D. Tillman, W. D. Gallup and R. MacVicar, 1954. A modified metabolism stall for steers. J. Anim. Sci. 13:504-510.

Olubajo, F. O. and V. A. Oyenuga, 1970. Digestibility of tropical pasture mixtures using the indicator technique. J. Agr: Sci. 75:175-181.

Pond, K. R., J. C, Burns and S. D. Fisher, 1987. External markers-use and methodology in grazing studies. Proc. Grazing Livest. Nutr. Conf. pp 49-53. Univ. of Wyoming, Laramie.

Prigge, E. C., G. A. Varga, J. I. Vicini and R. L. Reid, 1981. Comparison of ytterbium chloride and chromium sesquioxide as fecal indicators. J. Anim. Sci. 53:1629-1633.

Ramírez-Reyes, F., 1971. Comparación del método óxido crómico-lignina con el método convencional para estimar digestibilidad y consumo del pasto Pará (Brachiaria mutica) en bovinos, M.S. Thesis, Univ. P. R., Mayagüez, P.R. 